\title{
わかりやすい感性語による自動車検索の為の形状特徵抽出に関する基礎研究 Intelligent Car Selection for Beginner's Assist System
}

\author{
$\bigcirc$ 学 渡邊 慎一 (北海道工業大学) 正 川上 敬 （北海道工業大学） \\ 正 大堀 隆文 (北海道工業大学) 正 木下 正博 (北海道工業大学)
}

Shinichi Watanabe, Hokkaido Institute of Technology
Takashi Kawakami, Hokkaido Institute of Technology
Takafumi Oohori, Hokkaido Institute of Technology
Masahiro Kinoshita, Hokkaido Institute of Technology

A query to use at the time of a web search is important to control a result greatly, but the choice tends to depend on perception and experience, and it is difficult for a beginner's user to get the result that is an ideal. As one of the solutions, there is a search by the sensitivity word that the use is possible by human feelings intuitively soon. I limit it to a new car search, but build a new car search support system using sensitivity word as a search item. In this study, I try characteristic extraction of a design based on feelings map provided by Semantic Differential method.

Key word: Search by the feeling word, Semantic Differential method, query

\section{1 、緒言}

現在、日本では幅広い年齢層で自動車の利用が不可欠となって いる。自動車を購人する際の車探しの方法は、雑誌加ら探したりする 方法が一般的であるが、国内メーカーだけでも約200車種が存在し、 そのすべての車種を吟味するのは多くの時間を要する。したがって、 利用者の希望に添った自動車を提示する検索技術があれば有用で ある。しかし、現実にはwebによる検索サービスでは、ボディータイ プなどの自動車に関する知識を有していなければ効率よく検索でき ない。近年、自動車は所有することがステータスであったり、移動手 段の一つとして考える人が増加していたりなど、様々な自動車に対 する意識が存在している。また、専門的知識が不足している人の増 加が予想される状況では、直感的印象で自動車を検索する方法が 有効であると考える。よって本研究では、感性語を利用した自動車 検索システム構築の方法論について考察する。

\section{2. 初心者の為の自動車検索}

\section{1 本研究で扱う初心者}

本研究で対象としている初心者とは、検索エンジンの利用方法に 関して未熟な利用者を指寸。例として、キーワード検索では以下の 要点について議論できるとした。

(1)検索キーワードの決定方法

・目的情報の着目点が不明確である利用者

(2)キーワード入力方法

・単語入力、長文入力を選択できない利用者 (3)and・or・notなどの絞り込み機能の利用

・大量の検索結果から絞り込む方法を知らない利用者

(4)目的とする情報の基礎的な知識

・検索結果が目的としている情報と合致しているかの判断が出来な 以利用者

・キーワードそのものを決定出来ない利用者

ここで提案する初心者は大量に検索結果が提示されるような場合 に、効果的な検索において著しく不利となることを意味する。そして、 上記のポイントの(4)である、目的とする情報に関する知識を備えて いない初心者が増加すると予測できる分野が今回着目する自動車 検索分野である。

\section{2 自動車検索サイトの現状}

自動車検索サイトで提供されている検索方法は、価格帯検索・車 名直接入力・ボディータイプジャンル別検索などが主流となっている。 しかし、このような検索手法では、自動車についての知識が無けれ ば効率良く利用出来ない。ミニバン・SUVなどのジャンル選択による 検索は効果的方法であるが、この検索手法は大雑把にデザインが 表現されている為、大きさや乗車人数などに対して誤解を招きやす い問題が存在し、知識不足がネックとなるのが現状であり、誰もが直 感的に利用できるとは言い難いシステムである。このような初心者が 利用する場合でも、検索したい自動車の直感的印象を指定する事 であれば可能な場合がある。 


\section{3自動車購入時のポイント}

自動車を購入する際、どの因子を重要視するかはニーズによって、 価格・デザイン・燃費・人気など様々であるが、購入時の重視点をま とめると、図1で示すように使い勝手、購入金額、デザインの上位3項 目で半数以上を占めている事が解った。

この結果から、直感的な意見をくみ取るには上位3項目を利用し た検索方法が望ましいと言える。本研究ではこの中でも特にデザイ ンによる検索に着目し、効果的に初心者の為の検索手法を構築する ことを目的とした。

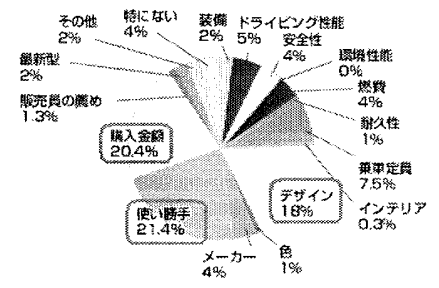

Fig. 1 Car purchase attention point

\section{3. イメージによる検索}

\section{1 自動車に対する印象の推定}

車のデザインに対する印象は人それぞれであるが、本研究ではレ ビューや自動車紹介文書などでも多く使用される形容詞、「かわい いに的を絞って考察した。まず、かわいいと評価される車の数台を 取り上げてみると、コンパクトカーや軽自動車などの小型車が多いこ とが解った。また、この中でも車高が高く、丸みを带びた車が特に可 愛いと評価される特徵があることから、各車の全長・全幅・全高を抽 出。小型車に対象を限定する為にエンジン排気量も検索条件として 採用。ヘッドライト形状も威圧的なデザインを省く為にライトの角数を 抽出。そして、最前・最後のピラー角度により大まかにだがボディー ラインを把握し、印象に近い車を絞り込むことが可能かを検証した。

検索対象車はトヨタ・ホンダを主とした55台。全長 $4200 \mathrm{~mm}$ 以下・ 全幅 $1700 \mathrm{~mm}$ 以下・排気量 $1500 \mathrm{cc}$ 以下・Aピラー30度以上・最後尾 ピラー 40 度以上などを条件とした結果、図2に示す 10 台まで絞り込 むことが可能となった。該当した10台には「可愛いと評価される車 も8台含まれており、この方法の可能性が示された。
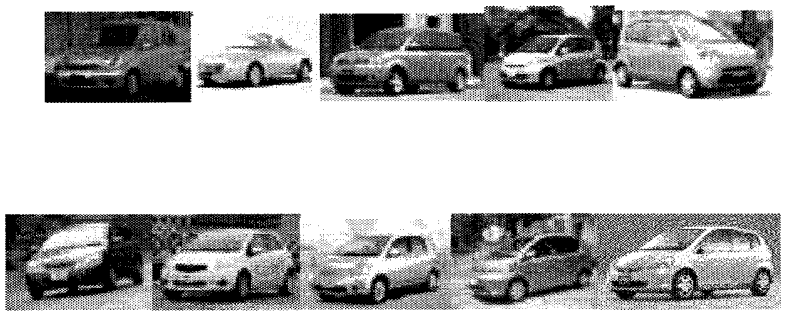

Fig. 2 Retrieval result
しかし、この方法ではレビューによって高く評価された印象だけが 考察対象となる為、複数の印象の有無を確認する事が難しい。また、 大量に存在する印象を個々に調查する事は非効率的な為、感性語 句の相関関係を抽出する事が望ましい。そこで、本研究ではSD法 を用いた因子分析を行うことにした。

\section{SD法を用いた因子分析}

\section{1 因子分析の利用目的}

$\mathrm{SD}$ 法とは、例えば「重い・軽い」な゙の相反する意味をもつ形容詞 対を複数種類用意し、評価対象に対して人が感じた程度を5段階評 価などで表すことで、対象に対する心理評価を行う手法である。この SD法の結果を因子分析することにより、印象を説明する少数の潜在 的な因子を求める。それにより、自動車評価に対する因子を抽出し、 それぞれの因子に対するデザイン特徴の考察を試みる。

\section{2 SD法による測定方法}

SD法を行うにあたり、形容詞対ならびに評価対象の選出を行った。 形容詞対は網羅的に収集を行った上で選出した。まず、参考文献に 添付された形容詞対データと自動車雑誌加、約500対の形容詞対 を抽出。それらを類似背に基づいて分類し、さらにデザインに関連し た対に絞り、33種類の対とした。なお、広範㭊の印象表現に対応 する為に、「角㲀った・丸い」などの客観的に形状を評価から「格好 良い・格好悪い」な゙の主観的な形容詞も含めた。

評価対象となる自動車は、検索対象車は中高年に人気があるトヨタ と若年層に人気があるホンダを主とし、その他に数台の外車を含め た40台とした。

\section{3 因子分析結果}

SD法によって得られた結果から因子分析を行い、表1のような結 果を得た。なお、因子数は kaiser 基準によって決定した。

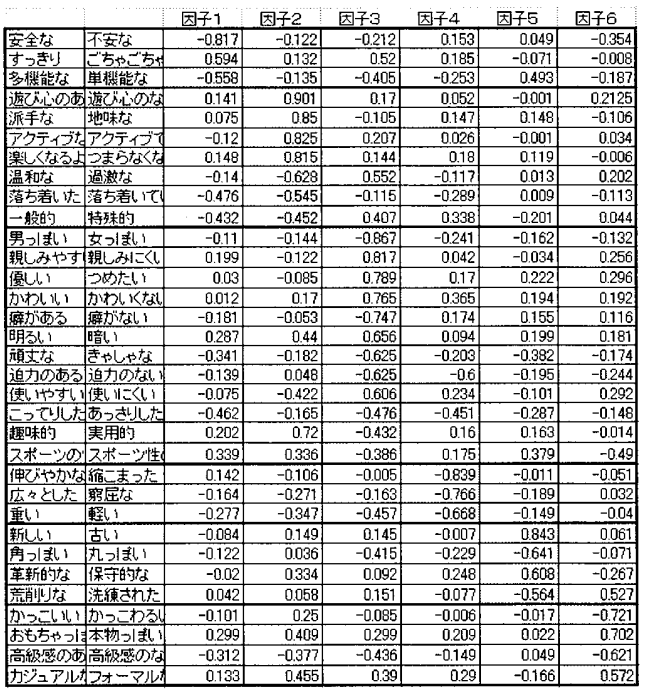

Table 1 Factor analysis result 
結果から自動車の印象は6つの因子に依存している事が解る。そ れぞれの因子が表現する意味は下記の通りである。

因子1：安全・ごちやごちゃ・多機能

因子2：遊び心無し·地味·非アクディブ・落ち着いた・一般的

因子3：男っぽい・親しみにくい・冷たい・可愛くない

因子 4 ：伸びやが・広々・重い

因子5：古い・角っぽい・保守的な・荒削りな

因子6：格好良い・本物・フォーマル

これらの結果から算出した、各自動車に対する因子スコアを因子 1 から因子6まで、対応付けてデザイン特徵の考察を行った。第4因 子・第3因子・第6因子の因子スコアに自動車デザインを対応させた グラフを図 3、図4、図 5 にそれぞれ示す。

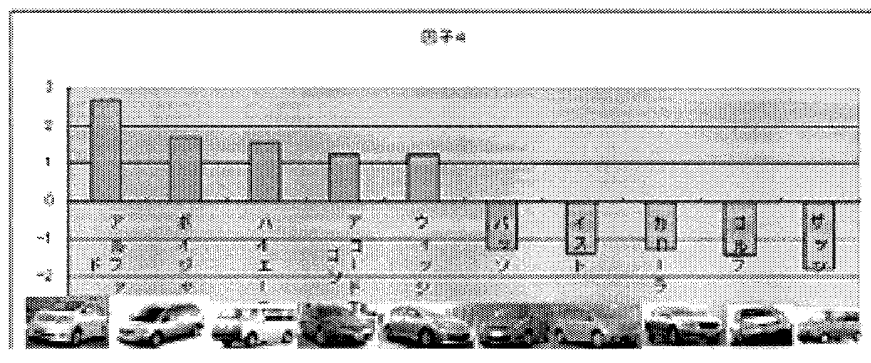

Fig.3 The fourth factor score graph

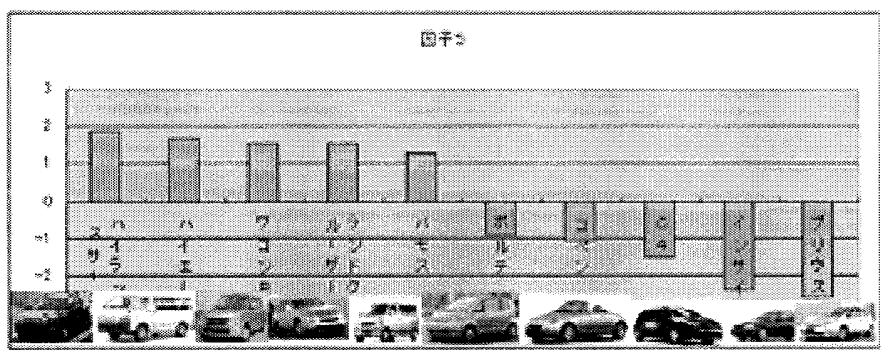

Fig.4 The fifth factor score graph

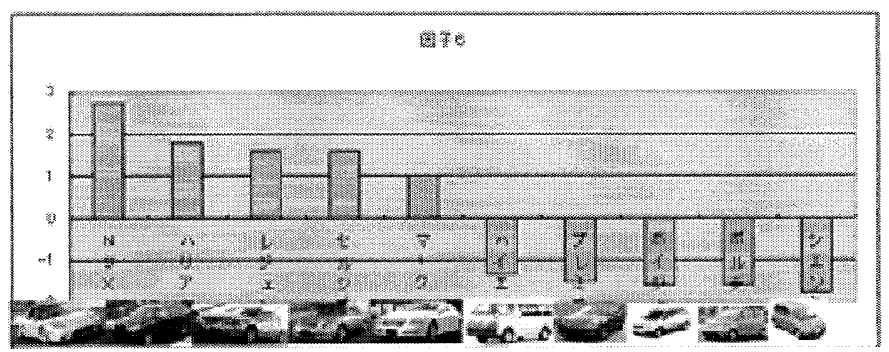

Fig.5 The sixth factor score graph

それぞれの因子を代表する画像特徴量を抽出すら為、全長・全 幅・全高・フロントグリル形状・ヘッドライト部分傾斜・全高、全幅に占 めるへッドライトの割合などを考慮に入れ考察を行った。まず、図2に 示第4因子「伸びやか・広々・重いりに対する各車の因子スコアを みる。ここでは、車内長を全長に対して大きく取っている事。また、前
後ピラーの角度も高めに設定され、車内空間を圧迫されていない事 が上位に該当するポイントとなっている事が解る。このように、正反対 に位置する印象の車と比較が可能な事により、印象を決定するデザ イン特徴の抽出が可能であった。同様に図40第5因子「古い.角っ ぽい・保守的な・荒削りな」でも、ヘッドライト付近の形状やピラーの 角度が低めであるほど、荒さが押さえられたデザインであると解る。

しかし、図40第6因子「格好良い・本物・フォーマル」では、ボディ 一サイズ・ボディーライン・グリル形状などに共通した特徽が無くデザ イン特徴を抽出する事が困難となった。

自動車のデザイン評価時に重視する要素として、個々の特徵も重 要であるが、フロント・サイド・リアの全体デザインバランスを総合的に 評価していると述べている論文もあり、今後は総合的なバランスの追 求に着目して調整を行う事が必要となる。

\section{5. 結言}

本研究は、情報処理の技術に詳しくない初心者をアシストするた めの検索システムの方法論を提案し、その有用性を示した。現在の 自動車検索サイトで主流である車名の直接人力や装備の選択を行う 方法に比べ、本研究は直感的に検索出来る条件を追求した。

新車発売後にも評価が遅れる事がないよう、外観による印象評価 を試みているが、自動車は印象を構成するデザイン要素が膨大に 存在する事から容易ではない。

今後の展望として、自動車ユーザーレビューの情報を積極的に活 用する事により、外観だけではなく使い勝手や乗り心地に対する印 象からも検索を行える事を目標とする。

参考文献

[1]斎藤 孟”自動車の基本計画とデザイン”

[2]篠原 昭“感性工学への招待”

[3]大澤 光“感性工学々情報社会”

[4]高木 幹雄“新編 画像解析ハンドブック”

[5]ガリバー自動車流通研究所レポート

(http://autos.aol.co.jp/)

[6]Laboo! 五感で探す車選び

連絡先

渡邊 慎一

E-mail:q06315@hit.ac.jp 